\title{
Yasmina Foehr-Janssens, La jeune fille et l'amour. Pour une poétique courtoise de l'évasion
}

\section{Mariagrazia Ricci}

\section{(2) OpenEdition}

1 Journals

\section{Édition électronique}

URL : https://journals.openedition.org/studifrancesi/4558

DOI : 10.4000/studifrancesi.4558

ISSN : 2421-5856

Éditeur

Rosenberg \& Sellier

\section{Édition imprimée}

Date de publication : 1 avril 2012

Pagination : 114-115

ISSN : 0039-2944

\section{Référence électronique}

Mariagrazia Ricci, «Yasmina Foehr-Janssens, La jeune fille et l'amour. Pour une poétique courtoise de l'évasion », Studi Francesi [En ligne], 166 (I | LVI) | 2012, mis en ligne le 30 novembre 2015, consulté le 19 novembre 2021. URL : http://journals.openedition.org/studifrancesi/4558 ; DOI : https://doi.org/ 10.4000/studifrancesi.4558

Ce document a été généré automatiquement le 19 novembre 2021.

\section{(c) 9 (i) $\Theta$}

Studi Francesi è distribuita con Licenza Creative Commons Attribuzione - Non commerciale - Non opere derivate 4.0 Internazionale. 


\title{
Yasmina Foehr-Janssens, La jeune fille et l'amour. Pour une poétique courtoise de l'évasion
}

\author{
Mariagrazia Ricci
}

\section{RÉFÉRENCE}

YASMINA FOEHR-JANSSENS, La jeune fille et l'amour. Pour une poétique courtoise de l'évasion, Genève, Droz, 2010 («Publications Romanes et Françaises», CCXLIX), pp. 223.

1 Y. Foehr-Janssens analyse quelques textes majeurs de la littérature courtoise du XII siècle afin de dresser l'image littéraire de la «demoiselle» et d'établir son rôle dans le discours amoureux. La première partie, au titre La fugue et l'amitié, analyse les deux contes idylliques par excellence: Pyrame et Thisbé (Thisbé ou la poétique de l'évasion, pp. 45-73) et Floire et Blanchefleur (Blanchefleur ou le don de l'amitié, pp. 75-112). Dans la deuxième partie, intitulée Dans les interstices du roman courtois: Thomas, Chrétien, Marie, l'A. se concentre sur les œuvres majeures de la littérature narrative du XII ${ }^{\mathrm{e}}$ siècle: le Tristan de Thomas (Iseut ou la 'fin'amor' rejouée, pp.115-143), les romans de Chrétien (Chrétien de Troyes, les demoiselles errantes et la coutume de Logres, pp. 145-178) et les lais de Marie de France (Marie de France: sauver Didon, libérer Iseut? La fugue à l'état héroïque, pp. 179-204). Y. Foehr-Janssens conclut qu'il est impossible de reconnaître une véritable autonomie à toutes ces figures féminines, qui paraissent toujours se situer dans une position subordonnée par rapport aux personnages masculins, et qu'en somme «la voix féminine reste la voix écho» (p. 43). 